\title{
Decision-making about children's mental health care: ethical challenges
}

\author{
Moli Paul
}

Abstract Children and young people are usually referred to specialist child and adolescent mental health services (CAMHS) by adults because of concerns raised by other adults. Most CAMHS consider them from a developmental perspective and as individuals in the context of their families and other relationships/ systems. In this article I discuss ethical and legal challenges posed by making decisions with and about children and young people within CAMHS, with particular reference to duty of care; the rights of minors' and parents'; capacity and consent; and disagreement between decision-makers. It is important to involve children and young people in decision-making, and I suggest ways of acheiving this.

Although child and adolescent mental health services (CAMHS) differ, they generally consider children and young people as individuals, at varying stages of physical, psychological (including emotional) and social development, and in relation to/in the context of their families and other relationships/services such as peers, teachers and schools (Health Advisory Service, 1995). This article refers to specialist, out-patient CAMHS within the National Health Service (NHS) in the UK.

Clinicians should work within the law and organisational (NHS) contracts, and pay heed to professional and general health care ethics and guidelines. The requirements of these usually overlap but may sometimes be different or even contradictory. Consequently, although this article is primarily about ethical deliberations, the law and guidance documents will also be considered.

The term 'child' will be used to cover children and young people, and to denote a relationship ('the child of his parents'). The legal term 'minor' will be used to denote an individual under 18 years of age, when the separate status of individuals under the age of majority is emphasised.

\section{Determining to whom a duty of care is owed}

Child and adolescent mental health services receive referrals about children, often as the result of the concern of parents or health, education or social care professionals, rather than of the child. Sometimes referrals are made when the children do not think they have a problem and do not want to change, or when the possessor of the primary problem is not the child (for example, when a parent is depressed and finds it difficult to manage the needs/demands of the child). The child's symptoms may be a consequence of systemic factors such as family relationship problems rather than individual factors alone. Indeed, a significant number of interventions are undertaken with parents/carers, the family and other services (for example, behavioural therapy, family therapy and consultation respectively).

Within multidisciplinary CAMHS, differing professions may use differing terminology ('patient', 'service user', 'client') or the terms may be used interchangeably. Terminology is important because different concepts should be associated with differing rights and claims and therefore differing responsibilities and duties. It cannot even be assumed that all professionals in CAMHS share the same professional ethics or the scope and limits of concepts such as duty of care. The need for shared ethics has been identified but remains a challenge for service providers (Tavistock Group, 1999). For this reason, it should be noted that this article is written by a psychiatrist.

The bipartite decision-making partnership between patients and their health care professionals is complicated in CAMHS as minors have parents or carers, making the relationship at least tripartite. The strong emotional bonds between child and parent, including the parents' deep personal interest in the child's future and the parent's knowledge of the child and the child's situation, are proposed by some as reasons for suggesting that parents are the

Moli Paul is a senior lecturer in child and adolescent psychiatry at the University of Warwick (Division of Health in the Community, Warwick Medical School, Coventry CV4 7AL, UK. E-mail: moli.paul@warwick.ac.uk) and an honorary consultant with South Warwickshire Primary Care Trust. Her research interests include consent, individual and group-based health care decision-making and the comparison of adults' and minors' decision-making. 
most appropriate and primary decision-makers about their child's best interests (Rachels, 1989). At times, such reasoning may be invalidated, for example when there are child protection issues or when the child is capable of balancing her present and future needs. At a practical level, parental support and cooperation are required for most health care interventions to be effective.

For all these reasons there may be times when it is unclear to whom a duty of care is owed. If a duty arises from the 'special' doctor-patient relationship, the clearest duty is that to the child as the referred patient. It is less clear whether parents and siblings count as 'patients'. Parents may be brought within this special relationship when they act as their child's proxy decision-maker, advocate or representative. CAMHS professionals might argue that a duty of care to the child implies some duty of care to the child's family.

If a duty of care correlates with the rights of others, then parents and siblings, as service users and individuals given professional advice, have negligence-related legal rights. What is unclear is whether they can claim that a clinician should act for their benefit when their child/sibling (and not they themselves) has been referred to that clinician.

\section{Balancing duties to minors with duties to their parents/siblings}

When, as is often the case, the benefit of the referred child and of other family members coincide, identifying distinct duties may be pointless. It is only when benefits do not coincide, and may even entail disadvantage or harm to other family members, that distinctions become important, for example if a mother is advised to spend individual time with one child, but does not have enough time do the same with her other three children, the other children are disadvantaged. Under such circumstances consideration of who can consent does not help us to 'do the right thing', as the real issue is one of justice (Graham \& Foreman, 1995), i.e. whose interests/rights ought to take priority.

\section{Bestinterests}

When a court determines any question with respect to the upbringing of a child, the child's welfare should be the court's paramount consideration (Children Act 1989 (hereafter called the Children Act), s1.1). This welfare is often referred to in terms of the child's best interests.

The best interests principle is often evoked when decision-makers disagree about what should happen to a child. It can be very helpful, allowing benefits and harms to be balanced, although it is not without problems: children have different interests (Box 1) that may clash; decision-makers may hold differing values (Fulford et al, 2002) or hold conflicting views about how to balance welfare.

For example, basic and developmental interests may or may not be valued by children but are usually valued by adults on children's behalf and by those adults for their own sakes (most parents would not want to lose their child). Interests that promote benefit may be counted twice (the interests of the current child and the interests of the adult-to-be).

\section{Box 1 The interests of children}

Within Section 1 of the Children Act 1989 it is stated that when a court determines any question concerning a child's upbringing, the child's welfare shall be paramount and that under the powers of the Act the court shall have regard to the following:

- the ascertainable wishes and feelings of the child (considered in the light of his age and understanding)

- the child's physical, emotional and educational needs

- the likely effect on the child of any changes in circumstances

- the child's age and gender; any background characteristics of the child that the court considers relevant

- any harm the child has suffered or is at risk of suffering

- how capable each if the parents, and any other person in relation to who $\mathrm{m}$ the court considers the question to be relevant, is of meeting the child's needs.

Eekelaar (1986) categorised the interests of children as follows:

- basic interests - the minimal expectation that children's general physical, emotional and intellectual care should be provided in the main by their caregivers

- developmental interests - their capacities should be developed to their greatest advantage in order to minimise and 'avoidable prejudices incurred during childhood' (p. 170), i.e. they should be treated in ways that enable them to enter adulthood as equals with their peers and as unfetterd as possible by their family or personal circumstances

- autonomy interests - the freedom to choose lifestyles and relationships according to their inclinations 
Children's views of what is in their own best interests may be discounted as being age-specific and therefore transient. However, age-specific values often fulfil developmental needs and should not be discounted provided they are value-based decisions and not just preferences (Ekman Ladd \& Forman, 1995). Children's basic and developmental interests may be valued more by adults than children's autonomy interests (Eekelaar, 1986) although this has been criticised, as it may subjugate respect for children's choices, worth and dignity and emphasise 'normal, natural and needs' rather than 'context, culture and competencies' (Alderson, 2000: p. 55).

The welfare principle has differing applications in public and private law and should not be considered limitless (Bainham, 1998). For example, it does not apply to 'adult issues' such as divorce, even where these affect children. It only comes into play when 'significant harm' has been established in public proceedings (e.g. in the form of care orders under the Children Act 1989) and in the juvenile justice system, it is balanced against the safety of the public.

The concept of best interests is only applied to adults who lack capacity (Re F (Mental Patient: Sterilisation) [1990]) but can be applied to all minors regardless of their capacity. This raises the following questions:

- Are minors' best interests emphasised because we basically doubt that minors have meaningful capacity? If so, is this justified?

- When is it relevant to consider anyone's best interests? If it is only relevant for those who lack capacity, should we stop considering the best interests of minors who have capacity? If the justification for considering best interests is not a lack of capacity, what is the justification and why is it not applied equally to all individuals, regardless of age?

\section{Balancing rights}

\section{Minors' rights}

There is conflicting philosophical and jurisprudential theorising about whether or not children are rights-holders and, if they are, what rights they might legitimately demand (Fortin, 1998). Over the past century and a half there has been a shift from children's rights to protection towards, but not to, their rights to self-determination. Children's rights to choose for themselves are sometimes discussed in terms of giving them adult rights or rights against parents.

The United Nations Convention on the Rights of the Child 1989 and the Children Act grant the child participatory decision-making rights. Providers of health care are thereby obliged to give minors any information necessary to enable their full participation in decision-making about matters that concern them, although it does not mean that children must be the final decision-makers (Lansdown, 2000). The European Convention on Human Rights 1950 and the Human Rights Act 1998 do not specifically mention children's rights but do permit minors' consent to be seen from a rights perspective by acknowledging the role of third parties (children) in cases between adult individuals (the child's parent(s)) and the state (Fortin, 1998). Although the Mental Health Act 1983 can be applied to minors, it does not apply to children treated in the community, and therefore rights flowing from this Act will not be discussed here.

To be meaningful, rights must be enforceable (Montgomery, 1992). In relation to health care this might be better achieved by extending to minors the law related to adult consent rather than by adding to the rights that children can claim because of their legal minority (Masson, 1991), and by acknowledging children as persons with rights rather than objects of concern. However, giving children adult rights might undermine their well-being by undermining the family, the very structure within which their interests are most likely to be maximised (Ross, 1998).

\section{Parents' rights}

In relation to their children's health care, parents have:

- rights on behalf of their children, as proxy decision-makers or legal representatives;

- rights as parents because of the importance of family integrity (Goldstein et al, 1979) or family autonomy (Ross, 1998) within liberal societies; here, parents decide what is in the best interests of their family rather than of the child in isolation, although the former is said to follow the latter (unless there are child protection concerns);

- rights as those responsible for children; accessing health care is identified as part of parents' responsibilities towards their child; the state and its agencies therefore have duties to support parents with this task (Children Act);

- rights, as individuals, to respect for private and family life (Human Rights Act, Article 8).

A proxy decision-maker is no longer required once a child can consent for herself. A representative is not required when the child can advocate for herself and can directly claim legal and political rights. Parental rights may last as long as the legal duration 
of parenthood but parents' rights as individuals continue indefinitely. Legally, it is the concept of parental responsibility (Box 2) that is the most pertinent to consent, especially as not all parents automatically have parental responsibility but some non-parents do.

\section{Box 2 Definitions}

Parental responsibility (Children Act 1989)

- This refers to all the rights, duties, powers, responsibilities and authority which by law a parent of a child has in relation to the child and his property

- Where more than one person has parental responsibility, each may act alone and without the other in meeting that responsibility

- A person who has care of the child (but not parental responsibility) may do what is reasonable to safeguard or promote the child's welfare.

Who has parental responsibility?

- Not all parents have parental responsibility

- Both parents will have parental responsibility if they were married at the time of the child's conception, or at birth, or at some time after the child's birth

- If the parents have never been married, only the mother automatically has parental responsibility, but the father may acquire that status by order or agreement

- Parents who do not have parental responsibility none the less play an essential role in determining best interests and may have a right, under the Human Rights Act 1998, to participate in the decisionmaking process

- People other than parents may acquire parental responsibility by being appointed as a guardian or on the order of a court.

The inherent jurisdiction of the High Court

- This is derived from the Crown's obligation to protect its subjects

- One aspect is parens patriae, the parental jurisdiction of the Crown to which all British children are potentially subject

- Another aspect is wardship

- Where legal rights are uncertain, the High Court's decision regarding any proposed treatment relieves all parties of any criminal or civic liability. There may, however, be constitutional concerns if the Court is asked to use its inherent jurisdiction in opposition to the will of Parliament, because the inherent jurisdiction is derived from the sovereign (Bedingfield, 1998).

Adult capacity

- Re C (Refusal of Medical Treatment) [1994] has established that an adult patient should be able to 'comprehend and retain information about the treatment, believe it and weigh it in the balance to arrive at a choice' (p. 36).

Minors' capacity

- Guidance on assessing minors' capacity is provided by the British Medical Association (2001)

- The term 'Gillick-competence' is often used. It derives from Lord Scarman's statement in Gillick that 'parental right yields to the child's right to make his own decisions when he reaches a sufficient understanding and intelligence to be capable in making up his mind on the matter requiring decision' (p. 422)

- Gillick and subsequent case law on minors' capacity requires greater or additional requirements than adults' capacity, e.g. minors should:

- be capable of choosing wisely and in their best interests (Lord Scarman, in Gillick);

- demonstrate stability of choice as proof of a permanent aspect of their development or capacity (Lord Donaldson in Re R (A Minor) (Wardship: Consent to Treatment) [1992]. This contrasts with his own assertion in $\operatorname{Re} T$ (An Adult) (Consent to Medical Treatment) [1993] that an adult's capacity should be assessed only at the time his decision is made. Indeed, the knowledge that an adult can change his mind is part of giving valid consent);

- have 'a full understanding and appreciation of the consequences, both of the treatment in terms of intended and possible side-effects and, equally important, the anticipated consequences of a failure to treat' (Lord Donaldson in Re W (A Minor) (Medical Treatment) [1991]: p. 187);

- have a full understanding of the implications of refusing treatment and choosing to die (ReE [1993]). 


\section{Balancing rights}

Application of Article 12 of the United Nations Convention on the Rights of the Child should mean that children's participatory rights are respected regardless of any legal definition of capacity (Shield \& Baum, 1994). The right to have the final say, however, may be mediated through the law on consent (see below). A conflict of rights may only be highlighted when there is disagreement about treatment. There is no simple answer to how rights should be balanced. When rights collide, justice should be considered in relation to competing claims. This can be done by considering how justified, appropriate, proportionate, applicable and necessary is the overriding of each right in question. Such reasoning should be documented.

\section{Who decides?}

There are two types of decision-maker: those who take part and those who have the final say. Guidelines for good practice state that 'The aim of decision-making is always to reach consensus' (British Medical Association, 2001: p. 124).

Children should be given the time, support and advice from their parents and health care professionals to assist them with decision-making. If a child does not consider herself to be a partner in the decision-making process she will not actively participate as a decision-maker. It is therefore imperative that clinicians ensure that children and parents know about children's participatory rights and that they facilitate children's decision-making, even when children lack capacity to consent. Competent children should also be encouraged to involve their families in decision-making.

Having the final say may depend on who:

- gives/refuses consent (see below)

- expresses objection to the intervention, whether this amounts to competent refusal or not; this type of final say may function:

(a) when force is unjustifiable because the intervention:

- would result in too little harm-avoidance or benefit;

- does not have the evidence-base to prove its benefit (Paul et al, 2000); or

- is unlikely to succeed without cooperation

(b) when the degree of coercion is unacceptable because it:

- does not respect the human dignity of the child (some might argue that this means that coercion is never justified);

- requires too much force (even psychological interventions may require the child to be physically or emotionally 'dragged to the clinic');

- would impair family or therapeutic relationships (present and/or future).

\section{Who can consent and refuse?}

For consent to be valid,

'it must be given voluntarily by an appropriately informed person (the patient or where relevant someone with parental responsibility for a patient under 18) who has the capacity to consent to the intervention in question' (Department of Health, 2001a: p. 4).

This definition identifies three aspects of consent: capacity, information and voluntariness. Decisionmaking is often considered to be part of capacity. Here, it is useful to consider it as a fourth aspect of consent because of the importance of establishing whether a child is an active decision-maker.

The law on minors' consent is evolving, but essentially, the following can give consent (Box 3, Table 1):

- 16- to 17-year-olds (except those who lack capacity);

- a Gillick-competent minor - Gillick v West Norfolk and Wisbech Area Health Authority [1986] (hereafter called Gillick) is the seminal case: interpreted narrowly, it only gives physicians authority to provide contraceptive advice and treatment to girls under 16 without parental consent, under certain circumstances, without fear of criminal or civil liability; interpreted broadly, it means that parents' rights to determine whether or not their child (under 16) has

\section{Box 3 Giving consent on behalf of minors}

Consent for the assessment or treatment of minors can be given by any of the following:

- a competent minor

- a person or local authority with parental responsibility

- a court

- a carer who does not have parental responsibility (but only if reasonable and necessary in order to safeguard or promote the child's welfare)

In the absence of consent, treatment can be legal in any of the following circumstances:

- within the scope of statutory laws such as the Mental Health Act 1983

- under aspects of the common law such as the concept of necessity 


\section{Table 1 Minors: who can consent?}

\begin{tabular}{|c|c|c|c|c|}
\hline $\begin{array}{l}\text { Age } \\
\text { (years) }\end{array}$ & Statute & $\begin{array}{l}\text { Capacity/competence required } \\
\text { from minors }\end{array}$ & $\begin{array}{c}\text { Parental } \\
\text { consent } \\
\text { acceptable? }\end{array}$ & Comments \\
\hline 16 or 17 & $\begin{array}{l}\text { The FLRA: s8(1) } \\
\text { makes it clear that } \\
\text { a 16-year-old can } \\
\text { validly consent to } \\
\text { medical treatment } \\
\text { The Mental Health Act }\end{array}$ & $\begin{array}{l}\text { Presumed to have capacity. } \\
\text { Same criteria as for adults, } \\
\text { i.e. must be able to: } \\
\text { (a) comprehend and retain information } \\
\text { material to the decision, especially } \\
\text { as to the consequences of having or } \\
\text { not having the intervention in question } \\
\text { (b) use and weigh this information } \\
\text { in the decision-making process } \\
\text { AND } \\
\text { Capacity should not be confused } \\
\text { with a health professional's assessment } \\
\text { of the reasonableness of the patient's } \\
\text { decision }\end{array}$ & Yes & $\begin{array}{l}\text { Assumption of capacity to } \\
\text { consent (but not refuse) } \\
\text { from age } 16 \text { years } \\
\text { This contrasts with ages at } \\
\text { which the law deems } \\
\text { minors to have other types } \\
\text { of capacity, e.g. the age of } \\
\text { criminal responsibility is } \\
10 \text { years }^{2}\end{array}$ \\
\hline$<16$ & $\begin{array}{l}\text { No statutory right to } \\
\text { give consent }\end{array}$ & $\begin{array}{l}\text { Those with Gillick-competence can } \\
\text { consent: this requires 'sufficient } \\
\text { understanding and intelligence to } \\
\text { enable him or her to understand fully } \\
\text { what is proposed' }\end{array}$ & Yes & $\begin{array}{l}\text { Acceptability of consent to } \\
\text { accept treatment is not } \\
\text { equated with acceptability } \\
\text { of refusal of treatment that } \\
\text { is life-saving or likely to } \\
\text { prevent significant harm }\end{array}$ \\
\hline
\end{tabular}

medical treatment ends when the child has achieved sufficient intelligence and understanding to make the decision for herself (Bedingfield, 1998);

- a person or local authority with parental responsibility;

- a court;

- a person caring for the child (but only when reasonable in the circumstances and necessary to promote or safeguard the child's welfare).

Department of Health guidance states that a competent minor's refusal should be overruled 'very rarely' but also that '[a]t all times you should be guided by the best interests of the child' (Department of Health, 2001b: p. 19). The child's ascertainable wishes, feelings and decisions are only part of his best interests and so clinicians may still be left in a quandary about when a minor's refusal can be overruled.

Professional guidance states that,

'it is unlikely to be ethically justifiable to override a young person's sustained, competent and informed refusal of treatment unless the treatment is essential to save or significantly enhance life' (British Medical Association, 2001: p. 124)

This is more definite, but the scope of significant enhancement needs further discussion, especially with regard to children's mental health.
The Department of Health and British Medical Association advice takes into account the law on minors' refusal, which is of necessity based on 'exceptional cases' that get to court (Box 4), as there is no general statutory right for minors to refuse treatment. Significant judicial paternalism in case law subsequent to Gillick has narrowed the interpretation of Gillick, in what has been called the 'retreat from Gillick' (Douglas, 1992):

- treatment can be given with parental consent, even if a child with capacity refuses treatment (Re R [1991]; Re W (AMinor) (Medical Treatment: Court's Jurisdiction) [1992]);

- under-12s can be admitted 'voluntarily' to psychiatric hospitals against their wishes through the exercise of parental custodial rights (Nielsen $v$ Denmark [1989]);

- minors' liberty can be restricted and they can be forced to undergo medical treatment for a mental disorder without the use of the Mental Health Act (Re K, W and H [1993]);

- if the Mental Health Act is in force and a child is competent, the court's inherent jurisdiction can override her consent or refusal (Re $R(A$ Minor) (Wardship: Consent to Treatment) [1992]).

Even the statutory rights of minors to refuse specific assessment under the Children Act has been 


\section{Box 4 Summaries of specific cases}

Re R [1991]

$\mathrm{R}$, a 15-year-old girl, refused antipsychotic treatment for bouts of a mental illness with symptoms of violent and suicidal behaviour. At the time of refusal, the child appeared lucid and rational. The local authority felt her to be Gillick-competent and thus withdrew their consent to treatment while applying for wardship under which the treatment could be administered without R's consent. $R$ was deemed incompetent by the High Court judge, who none the less said that if she had been competent, her parents or the court could not overrule her refusal.

The subsequent Appeal Court ruling upheld that a court acting in wardship could overrule the refusal of a Gillick-competent child and the child's parents or guardians. Lord Donaldson differentiated between capacity to consent and capacity to refuse treatment. He stated that, although the consent of either the competent child or the parents would suffice, refusal of both the child and the parents would be required for such a refusal to be valid. This contradicts the previous interpretations of Gillick, which assumed the refusal of a competent minor to be equally as valid as that minor's consent to treatment, and that the importance of parents' consent decreases as the capacity of the child increases.

Re W (A Minor) (Medical Treatment: Court's Jurisdiction) [1992] (the child is sometimes referred to as J)

The Appeal Court sought to distinguish between consent and refusal to consent to treatment. W was a 16-year-old patient with anorexia nervosa. She refused to be transferred to a specialist treatment unit but the court overruled this refusal, even though, at 16, she seemed to fall under the terms of the Family Law Reform Act 1969 (FLRA). The court quoted the argument of Lord Donaldson in Re R [1991] and considered that the FLRA did not cover refusal of treatment, only consent to treatment. The court ruled that a competent child under 18 years of age, whose refusal of treatment might result in 'irreparable consequences' could be required to have that treatment against her will if any person with parental responsibility consents to that treatment and a doctor considers it necessary. From the age of 16 , the right to consent was therefore shared with those who had the right to consent regardless of the FLRA, i.e. the parents and the court.

Re K, W and $H$ [1993]

The case revolved around three 15-year-old girls, two with unsocialised conduct disorder under secure accommodation orders and one with bipolar affective disorder for whom such an order was being sought. The hospital had parental or local authority consent for the minors' admission but when the minors complained about the administration of forced intramuscular injections, the health professionals sought specific issue orders under the Children Act (s8). The judge held that, even if the children were Gillick-competent, the hospital need not seek further court approval as parental consent had been given.

\section{Re R (A Minor) (Wardship: Consent to Treatment) [1992]}

$\mathrm{R}$, a 15 year-old-girl, under the care of a local authority, was detained under s2 of the Mental Health Act 1983 for a mental illness characterised by violent and suicidal behaviour. When, in a lucid interval, $R$ indicated that she would refuse treatment, the authority withdrew its consent and sought wardship proceedings to permit treatment without the child's consent. R's psychiatrist provided evidence of her capacity during the lucid phase. The judge stated that the girl's mental illness precluded her from being competent (not an automatic assumption in the case of adults, see Re C (Refusal of Medical Treatment) [1994]). The Appeal Court dismissed the Official Solicitor's appeal and stated that, even if a child were competent, the court's inherent jurisdiction could override her consent or refusal.

Nielsen v Denmark [1989]

The European Court of Human Rights held that the informal admission of a 12-year-old boy to a psychiatric hospital against his wishes but with parental consent was not a deprivation of liberty contrary to Article 5 of the European Convention on Human Rights. The reasoning was that, at 12, he was still of an age when it was normal for his mother to exercise her parental custodial rights in the interests of her child, even against his wishes.

overridden (South Glamorgan County Council v W and $B$ [1993]) and only the legality of reasonable force remains to be clarified (A Metropolitan Borough Council v DB [1997]). Lack of judicial respect for minors' refusal is particularly evident when refusal is likely to result in irreparable harm to the minor. In contrast, adult patients may refuse treatment for reasons which are 'rational, irrational or for no 
reason' (Sidaway [1985]: p. 904), even where the treatment is necessary to preserve life ( $\operatorname{Re} T$ (Adult: Refusal of Treatment) [1993]; Re C (Refusal of Medical Treatment) [1994]).

Although these are exceptional cases, clinicians who look to judicial reasoning to inform their own clinical and ethical thinking may be concerned, despite the Department of Health and British Medical Association guidance, because it is not clear:

- whether the giving and refusal of consent require different capacities;

- why treatment essential to save or significantly enhance life can be forced on minors with capacity but not on adults with capacity: if it is not the capacity to give/refuse consent that is pivotal, then what is the pivotal criterion?

- when it is relevant to consider anyone's best interests (see above);

- what constitutes significant enhancement of life;

- whether parental consent is acceptable in the face of a competent minor's refusal because of parents' proxy decision-making rights, parental responsibility or individual rights.

The current law in England and Wales may leave clinicians uncertain about what to do when the Gillick-competent child refuses but parents consent or vice versa. The American Academy of Pediatrics Committee on Bioethics (1995) sought to clarify the position in the USA and proposed seeking the informed permission (as opposed to consent) of parents and the assent of the child where appropriate, reasoning that the doctrine of informed consent can only be applied to children's health care when the child has decisional capacity and legal empowerment. Seeking such assent is taken to include not just obtaining the patient's agreement to the proposed care, but informing her about the proposed intervention and helping her to achieve a developmentally appropriate awareness of her condition. They proposed that when a child has decisional capacity and legal empowerment, the parents' views and involvement should similarly be sought, where appropriate, but not when refused by the patient. This approach has not been adopted in the UK.

Practically, refusal may be the result of fear or uncertainty about the consent process, or because of specific psychopathology such as oppositional behaviour (Batten, 1996). If so, providing the relevant information or changing the source of information, for example to an ex-service user, may be helpful. In order to know whether the requirements for consent are met by children, it is necessary to clarify whether the treatment-refuser is using language of responsibility or non-responsibility (McCabe, 1996) and whether decision-making would be swayed by parents' non-coercive opinions.

\section{When does someone have capacity to consent?}

The requirements for capacity are summarised in Box 2. Adults' capacity is specific to the decision to be made, whereas Gillick-competence and subsequent case law on minors' capacity at times goes beyond an individual decision and is more exacting.

The existing law suggests that it is acceptable to presume that people over 16 have capacity but those under 16 lack capacity, unless it is proven otherwise. Although there is advice on assessing capacity, there is little empirical evidence to support the above presumptions/perceptions. There have been suggestions that the age from which minors should be presumed to be able to consent should be lowered to 10-12 years (Department of Health, 1999) but this has not been reflected in the draft Mental Health Bill (Department of Health, 2002), and the draft Mental Incapacity Bill (Department for Constitutional Affairs, 2003) only applies to individuals older than 16.

If we separate 'capacity' (the legal ability of the person to consent to treatment) and 'competence' (the clinical ability of a person to consent to treatment) (Tan \& Jones, 2001), the literature on minors' competence tends to mirror the law on minors' capacity. Here, Alderson's (1993) three categories of tests of consent (by status, outcome or function) are useful. Tests of higher and more complex functional levels than adults' capacity (e.g. Reder \& Fitzpatrick, 1998) and tests of outcome (Batten, 1996) have been applied to minors.

The danger is that when children make risky choices or decisions that might result in significant harm to themselves or others (poor outcome), they are said to have failed tests for capacity/competence (tests of function) when actually they passed but their values or the outcomes of their choices were unacceptable to parents, professionals or the judiciary. This is dishonest and unjust, even if done beneficently and non-maleficently.

\section{Increasing benefit, honesty and justice within the current system}

Although law and guidance documents encourage children's participation in health care decisionmaking, there is lack of clarity about:

- whether competent refusal or best interests should prevail, and 
- whether or not capacity/competence should entail tests of function alone or tests of function $+/$-outcome $+/$-status .

This indicates inconsistent reasoning about minors' decision-making rights, especially when compared with adults' decision-making rights.

\section{Disadvantages of current law}

The current legal position (and guidance documents that take the law into account) has two major disadvantages. First, in relation to competent minors whose refusals are overridden, the following gains associated with the experience of decision-making may be lost.

- Contemporaneous gains: increasing the young person's sense of himself as an active and responsible participant in his own health care. This promotes adaptive and healthy psychological functioning, reinforces participation, boosts self-esteem and occasionally protects children by indicating any conflict of interests between parents and their child.

- Future gains: stimulating moral development, facilitating legal socialisation and offering learning opportunities that better prepare children for future joint or independent decision-making about their health.

- Other health related gains: improved compliance with proposed treatments and learning to choose courses of action that maintain or improve health.

Such gains may be forfeited because of loss of trust in professionals or parents, feeling unheard and therefore abandoning participation, learned helplessness or protest at being treated unfairly. Thus, what is needed is a system that protects these potential benefits without introducing other disadvantages.

Second, some argue that there is no consistent basis for categorical distinctions between children's and adults' rights regarding consent, as individuals either have rights because they are rational agents (in which case the same tests of function should apply to adults and minors) or individuals have normative rights (in which case there are good reasons to respect children as well as adults) (Dickenson \& Jones, 1996). This argument assumes that there are no relevant differences between children and adults.

Some might say it is obvious that there are differences between adults and children. If the relevant differences are of social, political or legal status, assessing minors' competence is still important in order to ascertain what weight to give their preferred choices, but there should be no assumption that their competent refusals will prevail. If the relevant difference is in their developmental abilities, those minors who pass the tests of capacity applied to adults should have their decisions respected regardless of poor outcomes. If the relevant factor is that decisions entailing poor outcomes are to be overridden, then this should apply equally to adults and minors. I suggest that it is the lack of specific acknowledgement of the first relevant difference, that of status, that underlies the inconsistencies within the law and guidance on minors' health care decision-making and consent. This difference in status does not permit consent to health care to be seen in isolation from other aspects of life, such as safety, basic needs and education.

\section{One practical response}

Decisions about whether or not to accept treatment should ideally be taken by children and their parents together. Rather than using the dichotomy of able to consent or not, children and parents should be consulted in relation to four different levels of decision-making: being informed, expressing a view, influencing decision-making and being the main decision-maker (Alderson \& Montgomery, 1996). Within the current legal situation, I suggest that it is better to be honest with children about the scope and limits of their involvement at all four levels. It is more respectful of children to be honest and explain the decision-making process in a way that seeks to maximise their participation while minimising the chances of them losing faith with the process.

We should tell them that their participation is important, that their voice should be heard and their values and preferences taken into account. We must then make good these statements. We should explain that any decisions they make that might result in significant harm or death are likely to be overridden because parents and society value their survival to a fit and functioning adulthood, when they will take over responsibility for themselves. They need to understand that their preferred choices and values are important and may often, but not always, be decisive. This is because, while they are minors, their parents are legally responsible for their care and health care professionals are legally responsible for their health care. Their decisions may also be unacceptable if they undermine their parents' ability to maintain their family, because in this society, it is considered that the family is the best organisation within which they can be raised.

Some may say that such an approach impairs children's rights because it basically leaves ultimate power in the hands of parents and carers rather than children. However, given the existing legal 
framework, such a practical approach is more likely to maximise children's participatory and consentrelated rights in the interim, while the debate about the legitimate scope of children's rights continues. Such debate must consider children's rights to health care in line with their rights to choose in other aspects of their lives; essentially, we need to decide under which circumstances children can choose to leave the protection of their parents and the state.

\section{References}

Alderson, P. (1993) Children's Consent to Surgery. Buckingham: Open University Press.

Alderson, P. (2000) Young Children's Rights. Exploring Beliefs, Principles and Practice. London: Jessica Kingsley Publishers.

Alderson, P. \& Montgomery, J. (1996) Health Care Choices: Making Decisions with Children. London: Institute for Public Policy Research

Americal Academy of Pediatrics Committee on Bioethics (1995) Informed consent, parental permission, and assent in pediatric practice. Pediatrics, 95, 314-317.

Bainham, A. (1998) Children - The Modern Law (2nd edn). Bristol: Family Law.

Batten, D. A. (1996) Informed consent by children and adolescents to psychiatric treatment. Australian and New Zealand Journal of Psychiatry, 30, 623-632.

Bedingfield, D. (1998) The Child in Need. Children, the State and the Law. Bristol: Family Law.

British Medical Association (2001) Consent, Rights and Choices in Health Care for Children and Young People. London: BMJ Books.

Department for Constitutional Affairs (2003) Draft Mental Incapacity Bill. Norwich: Stationery Office.

Department of Health (1999) Report of the Expert Committee. Review of the Mental Health Act 1983. London: Department of Health.

Department of Health (2001a) Reference Guide to Consent for Examination or Treatment. London: Department of Health.

Department of Health (2001b) Seeking Consent: Working with Children. London: Department of Health.

Department of Health (2002) The Draft Mental Health Bill. Norwich: Stationery Office.

Dickenson, D. \& Jones, D. (1996) True wishes: the philosophy and developmental psychology of children's informed consent. Philosophy, Psychiatry and Psychology, 2, 287-303.

Douglas, G. (1992) The retreat from Gillick. Medical Law Review, 55, 569.

Eekelaar, J. (1986) The emergence of children's rights. Oxford Journal of Legal Studies, 6, 161-182.

Ekman Ladd, R. \& Forman, E. N. (1995) Adolescent decisionmaking. Giving weight to age-specific values. Theoretical Medicine, 16, 333-345.

Fortin, J. (1998) Children's Rights and the Developing Law. London: Butterworths.

Fulford, K. W. M., Dickinson, D. L. \& Murray, T. H. (eds) (2002) Healthcare Ethics and Human Values. Oxford Blackwell Publishers.

Goldstein, J., Freud, A. \& Solnit, A. J. (1979) Before the Best Interests of the Child. London: Burnett Books.

Graham, P. J. \& Foreman, D. M. (1995) An ethical dilemma in child and adolescent psychiatry. Psychiatric Bulletin, 19, $84-86$.

Hardart, G. (2000) Including the family's interests in medical decision making in pediatrics. The Journal of Clinical Ethics, 11, 164-168.

Health Advisory Service (1995) Together We Stand. The Commissioning, Role and Management of Child and Adolescent Mental Health Services. London: HMSO.

Lansdown, G. (2000) Implementing children's rights and health. Archives of Disease in Childhood, 83, 286-288.
Masson, J. (1991) Adolescent crisis and parental power. Family Law, 21, 528-531.

McCabe, M. A. (1996) Involving children and adolescents in medical decision making. Developmental and clinical considerations. Journal of Pediatric Psychology, 21, 505516.

Montgomery, J. (1992) Rights to health and health care. In The Welfare of Citizens. Developing New Social Rights (ed. A. Coote). London: Rivers Oram Press.

Paul, M., Foreman, D. M. \& Kent, L. (2000) Out-patient clinic attendance. Consent from children and young people: ethical aspects and practical considerations. Clinical Child Psychology and Psychiatry, 5, 203-211.

Rachels, J. (1989) Morality, parents and children. In Person to Person (eds G. Graham \& H. LaFolette), pp. 195-206. Philadelphia, PA: Temple University Press.

Reder, P. \& Fitzpatrick, G. (1998) What is sufficient understanding? Clinical Child Psychology and Psychiatry, 3, $103-113$.

Ross, L. F. (1998) Children, Families and Health Care Decisionmaking. Oxford: Clarendon Press.

Shield, J. P. H. \& Baum, J. D. (1994) Children's consent to treatment. BMJ, 308, 1182-1183.

Tan, J. O. A. \& Jones, D. P. H. (2001) Children's consent. Current Opinion in Psychiatry, 14, 303-307.

Tavistock Group (1999) A shared statement of ethical principles for those who shape and give health care. $B M J$, 318, 249-251.

A Metropolitan Borough Council v DB [1997] 1 FLR 767, FD. Gillick $v$ West Norfolk and Wisbech Area Health Authority and Another [1986] AC 112; [1986] 1 FLR 223; [1985] 3 All ER 402,HL; [1985] 1 All ER 533, CA; [1984] 1 All ER 365.

Nielsen v Denmark [1998] 11 EHRR 175, Case 7/1987/130/ 181 Judgement, 27 November 1988.

Re C (Refusal of Medical Treatment) [1994] 1FLR 31; [1994] 1All ER 819; sub nom, [1994] 1 WLR 290, FD.

Re E [1993] 1 FLR 386.

Re F (Mental Patient: Sterilisation) [1990] 2 AC 1

Re K, $W$ and $H$ [1993] 1 FLR 854

Re R [1991] 4 All ER 177

Re $R$ (A Minor) (Wardship: Consent to Treatment) [1992] Fam 11, CA; [1992] 1 FLR 190

Re T (Adult: Refusal of Treatment) [1993] Fam 95; [1992] 2 FLR 458 .

Re W (A Minor) (Medical Treatment: Court's Jurisdiction) [1992] 3 WLR 758, CA, [1992] 4 All ER 627.

Sidaway $v$ Board of Governors of the Bethlem Royal Hospital and Maudsley Hospital [1985] AC 871.

South Glamorgan County Council $v$ W and B [1993] 1 FLR 574; [1993] Fam Law 398, FD.

\section{Multiple choice questions}

1 The following have parental responsibility:

a the mother

b a father married to the mother of the child at some time after the child's birth

c a step-father

$\mathrm{d}$ a father who never married the mother but who lives with the mother

e a mother whose child is in foster care.

2 Who can be assumed to be able to give consent for the treatment of a 14-year-old?

a the child

$\mathrm{b}$ the mother

c the father

d the step-father

e the social worker, when the child is in the care of the local authority. 
3 Which of the following are true statements?

a the Children Act 1989 states that the child's physical needs should be prioritised

b Department of Health guidance states that the child's physical needs should be prioritised

c the Children Act 1989 states that the competent child's health care decisions should always be respected

d Department of Health guidance states that the competent child's health care decisions should always be respected

e Department of Health guidance states that the competent child's refusal should only rarely be overruled.
4 The current legal tests of adults' capacity:

a can be applied to 17-year-olds

b can be applied to 15-year-olds

c are tests of outcome

$\mathrm{d}$ are tests of function

e are tests of status.

5 Parents can give consent for the medical treatment of their:

a 25-year-old son who has capacity

b 15-year-old son who has capacity

c 25-year-old son who lacks capacity

d 15-year-old son who lacks capacity

e 17-year-old son who has capacity.

\section{NOW OUT FROM GASKELLL}

\section{SAFEGUARDS FOR YOUNG MINDS Young People and Protective Legislation (Second edition)}

\section{By Richard White, Anthony Harbour and Richard Williams Edited by Richard Williams}

This extremely successful title is concerned with the law as it applies to the welfare, protection and management of children and adolescents in mental health services. The second edition has been thoroughly updated. There is an extra chapter on the new Human Rights Act as it applies to children and the law. Also, amendments to the Children Act 1989 consequent on legal judgements are explained. A series of chapters cover application of the Mental Health Act 1983 to young people, based on material developed from the College's successful section 12(2) training courses.

May 2004, Paperback, A4, 136pp, ISBN 190467102 0, Price £15.00

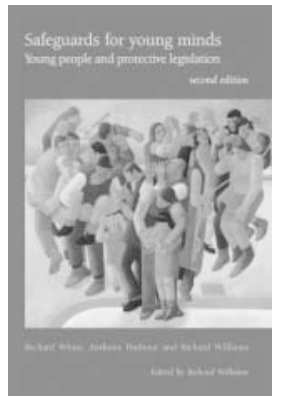

TO ORDER PLEASE CONTACT:

Book Sales, Royal College of Psychiatrists, 17 Belgrave Square,

London SW1X 8PG, UK. Tel: +44 (0)20 72352351 ext 146.

Fax: +44 (0)207245 1231. Website: www.rcpsych.ac.uk/publications 